\title{
STAVOVI NASTAVNIKA BIOLOGIJE I KEMIJE O OBRAZOVANJU ZA VREDNOVANJE UČENIKA
}

\author{
Renata Ruić1 ${ }^{1}$ Žaklin Lukša ${ }^{2}$ \\ ${ }^{1}$ Gimnazija Franje Petrića, Zadar, Obala kneza Trpimira 26, 23000 Zadar \\ renata.ruic@zd.t-com.hr \\ ${ }^{2}$ Gimnazija Josipa Slavenskog Čakovec, V. Nazora 34, 40000 Čakovec
}

\begin{abstract}
SAŽETAK
Rad prikazuje rezultate empirijskog istraživanja vrednovanja kod nastavnika biologije i kemije u osnovnoj i srednjoj školi. Istraživanje se temelji na stajalištima 220 nastavnika iz cijele Hrvatske prikupljenih posebno konstruiranim upitnikom koji se sastoji od otvorenih i zatvorenih pitanja, te skale sudova. Istraživanjem su obuhvaćeni nastavnici koji su završili nastavničke i nenastavničke studije, koji su kasnije polagali psihološkopedagošku grupu predmeta. Cilj istraživanja bio je utvrditi stavove nastavnika o kvaliteti njihova obrazovanja kojim su stekli kompetencije za vrednovanje učenika. Ispitivani nastavnici smatraju da predmeti potrebni za osposobljavanje nastavnika za rad nisu kvalitetno organizirani i odrađeni, a nezadovoljni su i realiziranim sadržajima i oblikom obrazovanja metodike (frontalni rad). Nastavni plan i program predmeta potrebnih za stjecanje nastavničkih kompetencija nije ispunio njihova očekivanja i stoga većina ispitivanih nastavnika smatra da tijekom studija nisu dobro pripremljeni za stvarne situacije u nastavničkoj praksi. Rezultati ovog istraživanja pokazuju da nema statistički značajne razlike u nezadovoljstvu stečenim kompetencijama između nastavnika koji su završili nastavničke studije i onih koji su nastavničke kompetencije stekli kroz dodatno pedagoškopsihološko obrazovanje.
\end{abstract}

Ključne riječi: nastavnik, metodika, vrednovanje, kvaliteta

\section{UVOD}

Vrednovanje u obrazovanju nastoji odrediti kako su i koliko dobro učenici svladali određeni sadržaj. Ono daje povratnu informaciju učenicima, nastavnicima, roditeljima i kreatorima obrazovne politike o uspješnosti uloženog truda svih sudionika u obrazovanju.

Posljednjih nekoliko godina Hrvatska nastoji postati zemlja znanja, ne bi li konkurirala na tržištu te gospodarski ojačala, pa se, kao jedan dio aktivnosti u tom smjeru, provodi vrednovanje obrazovnih institucija, a kao jednog od proizvoda tih institucija, vrednovanje znanja polaznika tih institucija provođenjem nacionalnih ispita i državne mature. Vode se diskusije oko pitanja da li ovakav način vrednovanja znanja daje pravu informaciju o stanju obrazovanja u Hrvatskoj i da li dovodi do poboljšanja cijelog obrazovnog sustava.

S druge strane, praćenje i ocjenjivanje učenika u razredu, koje doista može utjecati na bolje podučavanje i učenje, zanemareno je i prepušteno nastavnicima na brigu. Nastavnicima manjkaju pedagoško-psihološka i didaktičko-metodička znanja za praćenje i ocjenjivanje učenika, poznavanje školske dokimologije (Vrgoč, 2002), čega su, kako će ovo istraživanje i pokazati, sami nastavnici svjesni. Nastavnici također smatraju da izostaje osmišljena podrška sustava kako u inicijalnom obrazovanju, tako i u kasnijem usavršavanju nastavnika (Radeka i Sorić, 2005)

\section{Definiranje korištene terminologije}

Termini 'vrednovanje', 'praćenje', 'ocjenjivanje' različiti didaktičari, dokimolozi i psiholozi definiraju na različiti način. Ovdje je dan ograničeni pregled definicija, kako bi se čitatelj upoznao s nekim varijacijama termina, a na kraju su izložene definicije pojmova kojima se koristi ovaj rad. 
Vladimir Mužić i Hrvoje Vrgoč razlikuju vrednovanje, praćenje, provjeravanje, ispitivanje i ocjenjivanje (Mužić i Vrgoč, 2005). Vrednovanje obuhvaća sve aktivnosti kojima se dolazi do obavijesti o to me kako i koliko se ostvaruju ciljevi odgojno - obrazovne djelatnosti. Evaluacija je istoznačnica vrednovanju. Praćenje je onaj oblik vrednovanja kojim se u samom tijeku djelatnosti ustanovljuje njezino napredovanje, a time i poteškoće i nedostatci koje treba otkloniti da bi se time optimizirale mogućnosti uspješnog ostvarivanja ciljeva te djelatnosti. Provjeravanje je pojam koji se također temelji na ustanovljavanju stanja, bez obzira na polazne vrijednosti, odnosno kriterije, pa mu je i svrha identična svrsi praćenja. Razlika između tih dvaju termina zapravo je uglavnom u okolnosti da praćenje implicira kontinuiranost te aktivnosti, dok se provjeravanje obično veže uz iterativnost (njezino ponavljanje). Ispitivanje je sam postupak u kojem se, od subjekta kojeg se ispituje, nastoji ustanoviti situacija u svezi s usvojenosti ili, uopće, sa stanjem onoga što je objekt ustanovljavanja. Ono može biti usmeno, pisano ili činom u obliku obavljana nekog fizičkog rada. Ocjenjivanje se odnosi na davanje ocjena na temelju neke određene ljestvice ('brojčane ocjene') ili s pomoću (više ili manje konkretnog) tekstualnog opisa situacije onoga što se i kod koga se ocjenjuje ('opisna ocjena'). Ovaj termin obično implicira i obavijest roditeljima učenika i samim učenicima o njihovom uspjehu (Mužić i Vrgoč, 2005).

Milan Matijević (Bognar i Matijević, 2002) navodi kako odgojno-obrazovni proces polazi od potrebe realizacije određenih ciljeva, pa se očekuje i ocjenjivanje, odnosno procjena valjanosti te realizacije. $\mathrm{U}$ vezi s procjenom ostvarenosti tih ciljeva govori o unutarnjoj i vanjskoj evaluaciji. Dalje definira da unutarnja evaluacija, kao etapa odgojno-obrazovnog procesa, razumijeva praćenje, ocjenjivanje i vođenje, odnosno pedagoško usmjeravanje. Kasnije ne definira taksativno termine 'praćenje' i 'ocjenjivanje', ali između ostalog, napominje da je teško ponuditi jedinstven model praćenja i ocjenjivanja učenika (Bognar, Matijević, 2002.).

Autorice 'Psihologije obrazovanja' koriste termine 'procjenjivanje', 'mjerenje' i ocjenjivanje' (Vizek Vidović i sur., 2003.) Za procjenjivanje kažu da je to sustavni proces u kojem učitelj prikuplja podatke, analizira ih i tumači kako bi odredio u kojoj se mjeri učenici svladali obrazovne ciljeve. Mjerenje se odnosi na proces određivanja brojčane mjere nečijeg postignuća ili osobine, a ocjenjivanje uključuje prosudbu učenikova znanja u odnosu na neke unaprijed zadane kriterije ili u odnosu na druge učenike. Pri ocjenjivanju izmjereno znanje izražava se odgovarajućom ocjenom (brojkom ili slovom) koja prenosi poruku o količini vrijednosti izmjerenog znanja.

Vrednovanje se definira i kao ocjenjivanje koje uzima u obzir uvjete u kojima su postignuti neki rezultati (Andrilović i Čudina-Obradović, 1996) ili kao proces utvrđivanja stupnja postignuća ciljeva obrazovanja i odgoja te utvrđivanje čimbenika odgovornih za postignute ishode i učinke obrazovanja i odgoja (Pastuović, 1999)

Za potrebe ovog rada definicije termina uzete su iz Pravilnika o načinu praćenja i ocjenjivanja učenika u osnovnoj i srednjoj školi (MPS, 1995) te Prijedlog izmjena i dopuna pravilnika načinu praćenja i ocjenjivanja učenika u osnovnoj školi, gimnazijama te općeobrazovnih predmeta u strukovnim i umjetničkim školama (MZOS, 2010). Pod vrednovanjem podrazumijeva se praćenje i ocjenjivanje učenikovih postignuća i uspjeha u ostvarivanju zadaća nastavnog predmeta ili odgojno-obrazovnog područja tijekom cijele školske godine (MZOS, 2010). Pod praćenjem učenika razumijeva se sustavno bilježenje zapažanja o razvoju njegova interesa, motivacije i sposobnosti, njegovih postignuća u usvajanju odgojno-obrazovnih sadržaja nastavnog predmeta ili odgojno-obrazovnog područja, njegov 
odnos prema radu i postavljenim zadacima te odgojnim vrijednostima (MPS, 1995). Ocjenjivanje je postupak vrednovanja svih važnih činjenica o učenikovim postignućima tijekom praćenja, provjeravanja i ispitivanja, a izražava se ocjenom u skladu sa zakonom (MPS, 1995). Treba napomenuti da nastavnici najčešće u praksi koriste termin 'ocjenjivanje' i pod tim terminom podrazumijevaju i praćenje i ocjenjivanje učeničkih postignuća.

Termin 'nastavnik' u radu se koristi kao naziv za nastavnike predmetne nastave u osnovnoj školi te srednjoškolske nastavnike.

\section{Dosadašnje spoznaje i teorijska polazišta}

O obrazovanju nastavnika u Hrvatskoj pisali su mnogi a kako iscrpan i detaljan pregled prelazi opseg ovog rada nabrojit ćemo neke autore: Vlasta Vizek Vidović i Vlatka Domović (2008), Marko Palekčić (2008), Sofija Vrcelj i Marko Mušanović (2003), Mijo Cindrić (2003), Anton Kovačević i Berislav Žarnić (2003), Ilija Lavrnja (1999), Nenad Zekanović (1999), Frane Jakelić (1996); organiziran je znanstveni kolokvij 'Pedagoško obrazovanje nastavnika, Promjene u sustavu obrazovanja nastavnika 'u Splitu gdje su izlagali između ostalih Josip Milat (1995), Mirjana Nazor (1995) i Vladimir Rosić (1995). Velika većina autora se slaže da izobrazba nastavnika ne zadovoljava potrebe ni nastavnika ni učenika, posebno u području praćenja i ocjenjivanja učeničkih postignuća; nastavni programi više prate obrazovnu komponentu studija a manje potrebne kompetencije za nastavnički posao iako su nužne u kasnijem radnom okruženju te da bez reforme obrazovanja nastavnika nema ni reforme obrazovanja.

Tako Mužić i Vrgoč pišu kako je vrednovanje odgojnog i obrazovnog rada sastavni dio školskog sustava i njegove organizacije te bitan čimbenik stalnog razvijanja i unapređivanja odgojnog i obrazovnog rada (Mužić i Vrgoč, 2005). Smatraju da za novu koncepciju hrvatskog školstva i treba izgraditi i primjeren sustav vrednovanja. Vrednovanje je pedagogijska pojava koju treba znanstveno i stručno provjerenim postupcima nadopunjavati, nadograđivati, prilagođavati promjenama, potrebama vremena i prilika. Smatraju da je danas u praksi vrlo teško naći kvalitetnog 'vrednovatelja' što govori i o potrebi da u izobrazbu i usavršavanje tijekom rada bude uključeno i osposobljavanje za kvalitetno formativno vrednovanje.

Cveta Razdevšek-Pučko (2002) navodi upozorenje P. Blacka koji uvođenje nacionalnih testova svrstava među 'snove reformatora' o mijenjanju obrazovanja i tvrdi da su ti snovi utemeljeni na pretpostavci da je tako moguće podignuti standardne u obrazovanju. Ti reformatori zaboravljaju da je standarde moguće podignuti samo poboljšanjem nastave. Dalje piše kako se nastava može poboljšati suvremenim trendovima na području provjeravanja i ocjenjivanja znanja. U suvremene trendove spada odmak od psihometrijske paradigme, nužnost više pedagoškog provjeravanja koje bi pomagalo učenicima u učenju, uključivanje autentičnih oblika provjeravanja i ocjenjivanja, uravnoteženost učiteljevog (formativnog) i vanjskog (sumativnog) provjeravanja i ocjenjivanja, ostvarivanje nove kulture provjeravanja i ocjenjivanja znanja. Budući da ponajprije učitelj osigurava učenicima formativnu povratnu informaciju koja nije samo informacija u obliku točno-netočno, već učenika potiče na razmišljanje, samovrednovanje i metaučenje, nužno je poboljšati učiteljevo provjeravanje i ocjenjivanje znanja (Razdevšek-Pučko, 2002.).

Rađena su istraživanja u Hrvatskoj kako nastavnici percipiraju kvalitetu svojeg obrazovanja za nastavničke poslove, a među njima i vrednovanje učenika. Majda Rijavec, Renata Miljević-Riđički i Vlasta Vizek Vidović (2006) provele su istraživanje na 123 učitelja početnika i 334 studenta završnih 
godina s istih fakulteta i visokih škola. S ciljem ispitati profesionalne kompetencije učitelja početnika i studenata završnih godina. Od 20 područja znanja i vještina koje su se procjenjivale studenti su sebe procijenili kompetentnijim od učitelja-početnika u 8 područja, u deset područja nije bilo statistički značajne razlike, dok se učitelji-početnici procijenili kompetentnijim u samo dva područja. Autorice zaključuju da učitelji početnici doživljavaju 'šok realnosti'. Kao studenti imaju određena očekivanja i procjene svog posla koje nisu u skladu sa iskustvima koje doživljavaju kao učitelji-početnici. Nastavnici procjenjuju veći doprinos inicijalnog obrazovanja na sadržaj poučavanja, a kasnijeg usavršavanja na način poučavanja (Radeka i Sorić, 2005a). Autori istraživanja navode da je sve veća disproporcija između pedagoško-psihološkog i didaktičko-metodičkog osposobljavanja tijekom inicijalnog obrazovanja nastavnika dovela do takve marginalizacije sustavnog rada na nastavničkim umijećima da je tom pitanju danas nerijetko posvećeno manje od $5 \%$ ukupnog fonda sati nastavnih planova pojedinih nastavničkih studija. Nasuprot tome, među preporukama konferencije o promjenama obrazovanja nastavnika u Europskoj uniji (održane u Zagrebu 2002. godine) jest i da nastavno opterećenje iz pedagoško-psiholoških i didaktičko-metodičkih programa ne bi trebalo biti manje od $20 \%$ za nastavnike srednjih, a $35 \%$ za nastavnike osnovnih škola i odgajatelja predškolske djece. Dalje navode da stručnjaci osposobljavani za nastavničko zanimanje tijekom dodiplomskog obrazovanja značajno više vrednuju utjecaj njihova usavršavanja na znanje iz predmeta poučavanja u odnosu na nastavnike obrazovane nakon završetka dodiplomskog obrazovanja (ispitanici su učitelji razredne nastave, nastavnici osnovnih škola te nastavnici gimnazija i srednjih strukovnih škola). Autori naglašavaju da kada se uzme u obzir činjenica da je riječ o $10 \%$ nastavnika koji su završili nenastavničke studije, a koji su najčešće zaposleni u srednjim školama i to prije svega industrijskoobrtničkog i strukovnog tipa, zapostavljanje sustavnog rada sa spomenutim nastavnicima i posljedično zanemarivanje njihovih učenika vrlo je veliki problem. $U$ istraživanju provedenom 2004. godine isti autori (Radeka i Sorić, 2006) navode kako više od 9/10 nastavnika smatra da su u značajnoj mjeri osposobljeni za svoj rad. Autori ovog istraživanja su uočili da nastavnici koji bi napustili nastavničku profesiju ( $40 \%$ ispitanika) značajno lošijim procjenjuju svoj životni standard $i$ ugled svoje profesije ali se i osjećaju manje kompetentnim za nastavnički posao od nastavnika koji ne bi napustili svoju profesiju.

Marinković i Davidović-Mušica istraživali su sposobnost zadovoljavanja potreba učenika i sposobnost procjene rezultata učenja i učenikovih postignuća, između ostalog, uzorku od 67 ravnatelja, 267 mladih nastavnika s radnim stažom od 0-5 godina te 227 nastavnika na fakultetima i ostalim visoko školskim ustanovama (autorice ovu grupu nazivaju zaposlenicima) (Marinković i Davidović-Mušica, 2005). Rezultati pokazuju da sa ne razlikuju ravnatelji od nastavnika početnika i zaposlenika visokoškolskih ustanova u procjeni ovih dviju sposobnosti.

U istraživanju provedenom među učiteljima razredne nastave splitskih osnovnih škola $69 \%$ nastavnika se smatra djelomično osposobljenim za rad, $26 \%$ izrazito osposobljeno a $5 \%$ nedovoljno osposobljeno za rad (Blažević i Jukić, 2004).

Zdenko Kosinac je na uzorku od 114 studentica završne godine studija Visoke učiteljske škole u Splitu izvršio anketno ispitivanje s ciljem dobivanja informacija o stavu i mišljenju prema aktualnom nastavnom planu i programu (Kosinac, 2003). Rezultati su pokazali da oko $67 \%$ studentica smatra program prosječno dobrim a $31 \%$ studentica ima mišljenje da aktualni nastavni plan i program ne samo da ne zadovoljava njihova očekivanja i potrebe, nego ni društvene potrebe, pa ni potrebe škole. 
Većina ispitanica smatra da nastavni plan i program za izobrazbu učitelja treba aktualizirati pedagoško-metodičkim i općeobrazovnim ozračjem. Isti autor analizirao je gledišta 114 studentica studija Visoke učiteljske škole u Splitu o zastupljenosti i kakvoći metodika (Kosinac, 2003a). Dobiveni povratni iskazi studentica ukazuju da su potpuno neosnovane i neopravdane dvojbe onih subjekata u struci koji zastupaju ideju o preistaknutom značenju metodika na studiju za izobrazbu učitelja, o njihovoj daljnjoj redukciji ili čak ukidanju. Oko $60 \%$ studentica misli da bi trebalo više metodičkopraktičnih vježbi u školi, a oko $40 \%$ onih koje predlažu smanjenje fonda sati predavanja, a povećanje fonda sati metodičkih vježbi. Većina ispitanica (77\%) procjenjuje da se nastavnici metodike uočljivo razlikuju od nastavnika koji ne predaju metodike. Najveće razlike između djelovanja nastavnika metodike i nastavnika čija struka u užem smislu nije metodika su u načinu predavanja, objašnjavanju, uvjerljivosti, organizaciji nastave, praćenju i ocjenjivanju.

Anton Fontana je ispitivao iskustva i mišljenja apsolvenata nastavničkih i pedagoških fakulteta u Hrvatskoj o didaktičkom i metodičkom osposobljavanju 1989./1990. godine (Fontana, 1999). Od 236 apsolvenata $6 \%$ in smatra da su u najvećoj mjeri osposobljeni za praćenje i evaluaciju rada učenika, $29 \%$ smatra da su u velikoj mjeri osposobljeni dok ih $43 \%$ smatra da su u srednjoj mjeri osposobljeni za praćenje i evaluaciju rada učenika. $16 \%$ ispitanika misli da su maloj mjeri osposobljeni a $6 \%$ da nisu nikako osposobljeni za praćenje i evaluaciju rada učenika. Prosječna vrijednost osposobljenosti za praćenje i ocjenjivanje rada učenika jest 3,119. S druge strane, rezultati pokazuju prosječnu vrijednost osposobljenosti studenata za izvođenje nastave iz predmeta struke 3,691, što statistički gledano, inklinira broju 4, što u ovom upitniku znači da apsolventi smatraju da su za izvođenje nastave iz predmeta struke u većoj mjeri osposobljeni nego za nastavnički posao.

Dijana Vican Višić nakon analize dokumentacije 294 redovna studenta učiteljskog studija Filozofskog fakulteta u Zadru koja je pokazala da je uspješnost tijekom studija ispodprosječna (ocjena 2,89 ) a prosječna konačna ocjena 3,18 postavlja pitanja (Vican-Višić, 1996): (1) Jesu li budući učitelji doista obrazovani za ostvarivanje ciljeva i zadataka koje im odgojno-obrazovni sustav postavlja? (2) Možda ne trebamo bolje učitelje, ako se učitelji s ovim znanjem snalaze u praksi, ili ne trebamo sposobnije učitelje ako učenici kompenziraju (ne)znanje u obitelji, putem medija, izvanškolskim angažmanima, privatnim instrukcijama i sl.? (3) Kakvi su zahtjevi (i kriteriji) učitelja srednjeg uspjeha od učenika? (4) Dovodi li ovakva obrazovna razina učitelja dignitet struke u pitanje?

Da kvaliteta obrazovanja nastavnika nije upitna samo Hrvatske pokazuju rezultati TALIS istraživanja koje je proveo OECD (Ischinger, 2009). TALIS je međunarodna studija o rezultatima implementacije obrazovnih politika poticanja učinkovitog poučavanja i učenja na uzorku od 90000 nastavnika i ravnatelja unutar/izvan EU (23 zemalja). Glavni rezultat glasi 'Obrazovni rezultati učenika ne mogu nadići kvalitetu nastavnika'. Nastavnici ispitani u ovom istraživanju navode da se ne osjećaju dovoljno osposobljenim za nove izazove, traže bolju podršku kroz sustav praćenja i davanja povratne informacije a 55\% nastavnika traže više ciljanog treninga nego što trenutno primaju.

\section{Cilj istraživanja}

U domaćoj literaturi objavljeno je nekoliko istraživanja praćenja i ocjenjivanja učenika. Neka od tih istraživanja su se manjim dijelom odnosila i na predmete: biologija, kemija i fizika. Nije, međutim, poznato kako sami nastavnici ovih predmeta, osnovne i srednje škole, procjenjuju koliko su studiranjem osposobljeni za taj dio nastave, postoji li razlika u zadovoljstvu obrazovanjem za 
nastavničke poslove između nastavnika koji su završili nastavničke studije i onih koji su nakon inicijalnog nenastavničkog obrazovanja položili pedagoško-psihološku grupu predmeta.

U radu se analizira dio rezultata većeg istraživanja stavova nastavnika prema praćenju i vrednovanju kao odgojno-obrazovnom dijelu nastave, o načinima praćenja i ocjenjivanja učenika te o mišljenju nastavnika o vlastitoj kompetenciji vrednovanja učenika i to onaj koji se odnosi na kvalitetu njihovog obrazovanja za navedene poslove, kojim najčešćim oblikom provjere i koja znanja su njima vrednovana tijekom osposobljavanja za nastavničke poslove.

\section{MATERIJALI I METODE}

Podaci su prikupljeni anonimnim upitnikom konstruiranim za potrebe ovog istraživanja, koji je sadržavao pitanja zatvorenog i poluotvorenog tipa te skale sudova. Ispitivanje je provedeno tijekom 2008 i 2009 godine. Godinu dana prije samog istraživanja provedeno je baždarno ispitivanje uzorka na 40 ispitanika. Test pouzdanosti (Cronbach's Alpha) za cijelu anketu iznosi 0,749. Kad se izostave prvih 8 varijabli koje propituju opće podatke o ispitanicima (spol, godine staža i sl.) rezultati za test pouzdanosti je bolji: 0,762.

\section{Uzorak}

Istraživanjem je obuhvaćeno 220 ispitanika. Od toga je 208 nastavnica a 12 nastavnika, pa se ubuduće možemo izražavati u ženskom rodu. Nastavnice su informirane o svrsi i cilju istraživanja te im je zajamčena anonimnost. Na slici 1 vidi se da najviše ispitanika ima od 11- 20 godina staža (27,3 $\%)$.

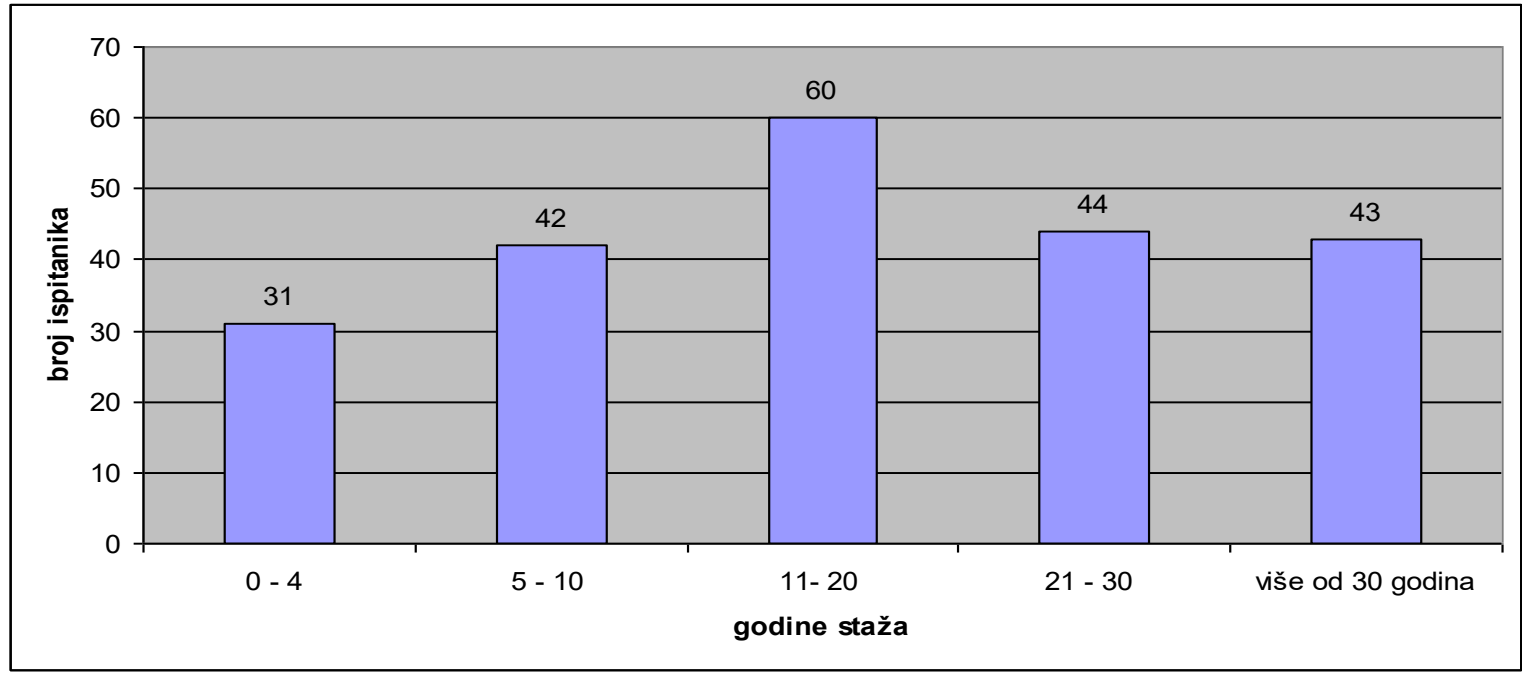

Slika 1 Raspodjela broja ispitanika po godinama staža

Najveći broj nastavnica koje su sudjelovale u istraživanju predaje i biologiju i kemiju, njih 76, zatim samu biologiju (71), pa kemiju (65 ispitanica). Osam nastavnika je predavalo neki srodan predmet.

Većina nastavnika radi u osnovnoj školi (125) zatim u gimnaziji (55) a ostatak nastavnika u srednjoj stručnoj školi (medicinska, ekonomska ili industrijska, njih 40).

Također, većina nastavnika ima visoku stručnu spremu (187), 30 ih ima višu stručnu spremu (i to nastavničkog smjera) a troje radi sa srednjom stručnom spremom (jedan u osnovnoj, drugi u srednjoj 
školi predaje kemiju a treći predaje biologiju u srednjoj školi). S višom stručnom spremom najviše ima nastavnica biologije, 13, od toga 12 nastavnica ima 30 i više godina staža.

Većina nastavnika $(79,1 \%)$ u nastavnom je zvanju, 10 \% ima zvanje nastavnika mentora, a 10,9 \% nastavnika savjetnika (relativno visok postotak nastavnika mentora i nastavnika savjetnika je posljedica je toga što je dobar dio anketnih upitnika skupljen je na Državnim natjecanjima iz biologije i kemije, te na stručnim skupovima za iste).

Od 220 ispitanika 72 \% završilo je nastavničko dodiplomsko obrazovanje, a 28 \% nenastavničko dodiplomsko obrazovanje. Najviše je nastavnika biologije i kemije koji su završili nastavničko obrazovanje (31\%), čistu biologiju predaju, također, obrazovani u nastavničkom obrazovanju (26\%), dok većina nastavnika koji predaju samo kemiju ima završeno nenastavničko obrazovanje (18 \% od ukupnog broja ispitanika a $62 \%$ od ispitanika koji predaju samo kemiju slušali su pedagoškopsihološku grupu predmeta nakon završenog inicijalnog obrazovanja).

$16 \%$ ispitanika radi u školi na selu, $43 \%$ u gradskom predgrađu ili manjoj gradskoj sredini a $41 \%$ u velikom gradu.

\section{REZULTATI I RASPRAVA}

Sastavni dio obrazovnog procesa je provjera znanja i ocjenjivanje. Učenike vrednuju i ocjenjuju od trenutka kad počine njihovo školovanje, a te ga ocjene prate cijeli život i osnova su za donošenje raznih odluka. Škole na taj način implicitno usmjeravaju njihov razvoj i oblikuje njihove ciljeve. Da su li nastavnici koji donose ocjene dovoljno osposobljeni da to čine?

Doprinos inicijalnog obrazovanja i dopunskog pedagoškog obrazovanja kompetencijama nastavnika procjenjivan je po Likertovoj skali od pet stupnjeva (jako se ne slažem - 1; ne slažem se - 2; neodlučan/na sam - 3; slažem se - 4; jako se slažem - 5). Rezultati su obrađeni programom SPSS.

Tablica 1 Mjere srednjih vrijednosti za sljedeće tvrdnje ( $\mathrm{N}=220)$

\begin{tabular}{|l|c|c|}
\hline Tijekom obrazovanja dobro sam osposobljen/a za praćenje i ocjenjivanje učeničkih postignuća. & M & \multicolumn{1}{c}{ SD } \\
\hline Primjenjujem način ocjenjivanja koji sam naučio/la tijekom obrazovanja. & 3,15 & 1,118 \\
\hline Predmeti potrebni za osposobljavanje nastavnika su vrlo kvalitetno organizirani i odrađeni. & 3,182 & 0,933 \\
\hline Nastavni plan i program predmeta je potpuno ispunio moja očekivanja. & 2,83 & 0,935 \\
\hline $\begin{array}{l}\text { Predmeti potrebni za osposobljavanje nastavnika su me dobro pripremili za stvarne situacije u } \\
\text { nastavničkoj praksi. }\end{array}$ & 2,79 & 1,092 \\
\hline $\begin{array}{l}\text { Vrlo sam zadovoljan realiziranim sadržajima metodike. } \\
\text { U obrađenim sadržajima metodike područje vrednovanje i ocjenjivanje je bilo dobro zastupljeno. }\end{array}$ & 3,17 & 0,990 \\
\hline $\begin{array}{l}\text { Obrazovanje za nastavnika bilo bi djelotvornije kad bi se nastavni planovi i programi iz metodika } \\
\text { prilagodili stvarnim poslovima u školi. }\end{array}$ & 2,75 & 1,084 \\
\hline $\begin{array}{l}\text { Obrazovanje za nastavnika bi bila djelotvornija kad bi se nastavni planovi i programi iz metodika } \\
\text { izvodili drugačije od frontalnog, predavačkog načina. }\end{array}$ & 4,43 & 0,669 \\
\hline
\end{tabular}

$U$ našem istraživanju većina se nastavnica ne slaže $s$ tvrdnjom da su tijekom obrazovanja dobro osposobljeni za vrednovanje učeničkih postignuća ili je neodlučna (63 \%) dok su Marinković $\mathrm{i}$ Davidović-Mušica dobili niži rezultat: srednja vrijednost nastavnika početnika za procjenu rezultata učenja i učenikovih postignuća u njihovom istraživanju je 2,61, zaposlenika 2,56 i kod poslodavca ravnatelja 2,79 (Marinković i Davidović-Mušica, 2005).

Rezultati našeg istraživanja pokazuju da u grupi nastavnica koje se smatraju da su dobro osposobljene za praćenje učenika tijekom školovanja njih $9 \%$ ima od 21-30 godina staža, a $10 \%$ više od 30 godina staža. Kako su prije tridesetak godina još djelovale pedagoške akademije i učiteljske 
škole, ovaj rezultat poklapa s rezultatima Anite Klapan (Klapan, 1990) koja je ispitivala stavove i mišljenja 160 nastavnika razredne nastave o njihovim praktičnom pripremanju za nastavnički poziv. Njeno istraživanje je pokazalo da je najviše dobrih strana imala nastavna praksa u nekadašnjim učiteljskim školama.

Statistički ne postoji značajna razlika u procjeni o osposobljenosti za vrednovanje tijekom studija između nastavnika koji su završili nastavničke studije i onih koji su završili nenastavničke studije (tablica 2). Varijable u t-testu su tretirane kao nezavisan uzorak.

Tablica 2 T-test za nastavnike s nastavničkih studija i nastavnike s nenastavničkih studija

\begin{tabular}{|l|c|c|c|c|}
\hline & $\begin{array}{c}\text { M nastavničko } \\
\text { obrazovanje }\end{array}$ & $\begin{array}{c}\text { M nenastavničko } \\
\text { obrazovanje }\end{array}$ & $\mathrm{t}$ & $\mathrm{p}$ \\
\hline $\begin{array}{l}\text { Tijekom obrazovanja dobro sam osposobljen/a za } \\
\text { praćenje i ocjenjivanje učeničkih postignuća. }\end{array}$ & 3,06 & 2,92 & 0,822 & 0,412 \\
\hline
\end{tabular}

Od ispitivanih nastavnika 44 \% nezadovoljnih osposobljenošću za praćenje i ocjenjivanje polazilo je nastavničke studije (97 od 158 nastavnika), a $18 \%$ nenastavničke studije (40 od 61 nastavnika s inicijalnim nenastavničkim studijem), što unutar njihovih skupina daje vrlo sličan postotak nezadovoljnih (61 \% odnosno $66 \%$ ). Zanimljivo je da nastavnici nezadovoljni svojom osposobljenošću dolaze iz redova onih sa završenom visokom stručnom spremom, dok $10 \%$ zadovoljnih svojom osposobljenošću za praćenje i ocjenjivanje učenika ima srednju ili višu stručnu spremu.

58 \% nastavnika se ne slaže s tvrdnjom 'primjenjujem način ocjenjivanja koji sam naučio/la tijekom obrazovanja' ili je neodlučna. U grupi koja primjenjuje način ocjenjivanja koji su naučili tijekom školovanja $12 \%$ ih ima više od 21 godine staža a $8 \%$ više od 30 godina. Vidimo da zadovoljni nastavnici opet dolaze iz grupe starijih kolega. Jednako (ne) primjenjuju način ocjenjivanja naučen tijekom osposobljavanja nastavnici koji su završili nastavničke studije i oni koji su završili nenastavničke studije ( $\left.M_{\text {nas }}=3,12 ; M_{\text {nenas }}=3,23 ; t=-0,611 ; p=0,542\right)$.

S tvrdnjom 'predmeti potrebni za osposobljavanje nastavnika su vrlo kvalitetno organizirani i odrađeni' čak 63 \% nastavnika se ne slaže ili je neodlučno. 12 \% nastavnika u grupi koji se slažu s ovom tvrdnjom ima više od 30 godina staža. Činjenica da ne postoji statistički značajna razlika između ispitivanih nastavnika koji su završili nastavničke studije i onih koji su naknadno položili pedagoškopsihološku grupu predmeta ( $\left.M_{\text {nas }}=3,12 ; M_{\text {nenas }}=3,07 ; t=0,387 ; p=0,699\right)$ dovodi u pitanje kvalitetu nastavničkih studija, kako po pitanju nastavnog plana pedagoških predmeta tako i po pitanju kvalitete izvođenja istih.

Tvrdnju 'nastavni plan i program predmeta je potpuno ispunio moja očekivanja' $75 \%$ nastavnika nije moglo potvrditi. Ovog puta i nastavnici s dvadesetogodišnjim i više iskustvom je bilo u većini neodlučno kako se vidi iz tablice 3 .

Tablica 3 Stavovi nastavnika ovisno o godinama radnog staža

\begin{tabular}{|c|c|c|c|c|c|c|c|}
\hline & & \multicolumn{5}{|c|}{ Nastavni plan i program predmeta je potpuno ispunio moja očekivanja } & \multirow[t]{2}{*}{ Total, \% } \\
\hline & & $\begin{array}{l}\text { jako se ne } \\
\text { slažem, \% }\end{array}$ & $\begin{array}{c}\text { ne slažem se, } \\
\%\end{array}$ & $\begin{array}{c}\text { neodlučan } \\
\text { sam, \% }\end{array}$ & $\begin{array}{c}\text { slažem se, } \\
\%\end{array}$ & $\begin{array}{c}\text { jako se } \\
\text { slažem, \% }\end{array}$ & \\
\hline \multirow{5}{*}{$\begin{array}{l}\text { Godina } \\
\text { staža }\end{array}$} & $0-4$ godine & 2,3 & 4,0 & 5 & 2,3 & 0,4 & 14 \\
\hline & $5-10$ godina & 0,9 & 9,0 & 7,7 & 1,4 & 0 & 19 \\
\hline & 11-20 godina & 1,8 & 8,6 & 10 & 6,8 & 0 & 27,3 \\
\hline & 21-30 godina & 0,4 & 5,5 & 7,2 & 5,9 & 0,9 & 19,9 \\
\hline & više od 30 godina & 1,4 & 3,8 & 7,2 & 6,6 & 0,8 & 19,8 \\
\hline \multicolumn{2}{|r|}{ Total } & 6,8 & 30,9 & 37,2 & 23 & 2,1 & 100 \\
\hline
\end{tabular}

Ruić, R., Lukša, Ž. 2017. Stavovi nastavnika biologije i kemije o obrazovanju za vrednovanje učenika. Educ. biol. 3, 1,15-26. 
I kod ove tvrdnje ne postoji statistički značajna razlika između nastavnika koji su završili nastavničke studije i onih koji su završili nenastavničke studije ( $\left.M_{\text {nas }}=2,82 ; M_{\text {nenas }}=2,84 ; t=-0,139 ; p=0,890\right)$.

Čak se $71 \%$ nastavnika ne može složiti s tvrdnjom 'predmeti potrebni za osposobljavanje nastavnika su me dobro pripremili za stvarne situacije u nastavničkoj praksi'. Pri tom $60 \%$ nastavnika koji se ne slažu s ovom tvrdnjom ima do 20 godina staža. 11\% nastavnika koji smatraju da su ih predmeti potrebni za osposobljavanje dobro pripremili za nastavničke poslove imaju više od 30 godina iskustva. Jednako razmišljaju nastavnici $s$ nastavničkih studija $i$ oni $s$ dopunskim pedagoškim obrazovanjem ( $M_{\text {nas }}=2,78 ; M_{\text {nenas }}=2,79 ; t=-0,051 ; p=0,959$ ).

S tvrdnjom 'vrlo sam zadovoljan realiziranim sadržajima metodike' 60 \% nastavnika se ili ne slaže ili je neodlučno. $12 \%$ nastavnika koji se slažu s ovom tvrdnjom ima više od 30 godina staža. Nema statistički značajne razlike između nastavnika s nastavničkim i nenastavničkim studijem $\left(M_{\text {nas }}=3,18\right.$; $\left.M_{\text {nenas }}=3,11 ; t=0,460 ; p=0,646\right)$.

$72 \%$ nastavnika se ne slaže ili je neodlučno kod tvrdnje 'u obrađenim sadržajima metodike područje vrednovanje i ocjenjivanje je bilo dobro zastupljeno' $(M=2,75 ; S D=1,084) .22$ nastavnika koji smatraju da je ocjenjivanje bilo dobro zastupljeno ima više od 30 godina staža. Nema statistički značajne razlike između nastavnika s nastavničkim i nenastavničkim studijem ( $M_{\text {nas }}=2,78 ; M_{\text {nenas }}=$ $2,79 ; t=-0,051 ; p=0,959)$.

S tvrdnjom ' obrazovanje za nastavnika bilo bi djelotvornije kad bi se nastavni planovi i programi iz metodika prilagodili stvarnim poslovima u školi' slaže se $93 \%$ nastavnika, a s tvrdnjom 'obrazovanje za nastavnika bi bila djelotvornija kad bi se nastavni planovi i programi iz metodika izvodili drugačije od frontalnog, predavačkog načina' $83 \%$ nastavnika.

Samo se 1,4 \% nastavnika ne slaže, a $6 \%$ in je neodlučno kod tvrdnje da bi obrazovanje nastavnika bilo djelotvornije kad bi se metodika prilagodila stvarnim poslovima, od toga šestero ima više od 30 godina staža. Kod ove tvrdnje postoji statistički značajna razlika između nastavnika s nastavničkih studija i onih s nenastavničkih studija. Nastavnici s nastavničkih studija skloniji su tome da se nastavni planovi i programi iz metodika prilagode stvarnim poslovima u školi (tablica 4.).

Tablica 4 T-test za nastavnike s nastavničkih studija i nastavnike s nenastavničkih studija

\begin{tabular}{|c|c|c|c|c|c|c|}
\hline & $M$ & SD & $\begin{array}{l}\text { M } \\
\text { nastavničko } \\
\text { obrazovanje }\end{array}$ & $\begin{array}{c}\text { M } \\
\text { nenastavno } \\
\text { obrazovanje }\end{array}$ & $t$ & $p$ \\
\hline $\begin{array}{l}\text { Obrazovanje za nastavnika bilo bi djelotvornije kad } \\
\text { bi se nastavni planovi i programi iz metodika } \\
\text { prilagodili stvarnim poslovima u školi. }\end{array}$ & 4,43 & 0,669 & 4,50 & 4,25 & 2,550 & 0,011 \\
\hline $\begin{array}{l}\text { Obrazovanje za nastavnika bi bila djelotvornija kad } \\
\text { bi se nastavni planovi i programi iz metodika izvodili } \\
\text { drugačije od frontalnog, predavačkog načina. }\end{array}$ & 4,26 & 0,845 & 4,25 & 4,28 & $-0,250$ & 0,803 \\
\hline
\end{tabular}

0,9 \% nastavnika se ne slaže, a 2,3 \% je neodlučno kod tvrdnje 'obrazovanje za nastavnika bi bila djelotvornija kad bi se nastavni planovi i programi iz metodika izvodili drugačije od frontalnog, predavačkog načina'. 1,4 \% od tih nastavnika ima više od 30 godina staža. Kod ove tvrdnje ne razlikuju se nastavnici s nastavničkih studija i onih koji imaju dopunsko pedagoško obrazovanje $\left(\mathrm{M}_{\text {nas }}=\right.$ 4,$\left.25 ; M_{\text {nenas }}=4,28 ; t=-0,250 ; p=0,803\right)$. 
Tijekom obrazovanja znanje predmeta potrebnih za osposobljavanje nastavnika provjeravano je usmenim ispitivanjem i pisanim zadaćama kod $75 \%$ ispitanika. $22 \%$ nastavnika pitano je samo usmenim ispitivanjem, a 0,9\% nastavnika je izjavilo da je pitano nekim drugim načinom. Nema velikih odstupanja po godinama staža. Postoji statistički značajna razlika između nastavnika s nastavničkim i nenastavničkim studijem ( $\left.M_{\text {nas }}=2,65 ; M_{\text {nenas }}=2,31 ; t=2,726 ; p=0,007\right)$. Nastavnici s nastavničkih studija češće su imali oba načina provjere znanja - usmeno ispitivanje i pisane zadaće.

Najčešće je provjeravano znanje činjenica (36\% ispitanika), a $33 \%$ ispitanika tvrde da su provjeravana četiri varijeteta znanja (znanje činjenica, razumijevanje, primjena znanje u poznatim situacijama i primjenu znanja u novim, nepoznatim situacijama). Nema statistički značajne razlike između nastavnika s nastavničkim i nenastavničkim studijem ( $M_{\text {nas }}=2,72 ; M_{\text {nenas }}=2,64 ; t=0,318 ; p=$ $0,750)$.

27 \% ispitanika prošlo je obrazovanje iz područja metodike kroz frontalni oblik rada, 4,5 \% kroz grupni rad, 4,0 \% kroz individualni rad, 11,4 \% kroz praktičnu nastavu, a 53 \% kombinacijom svih ili samo nekih oblika podučavanja (najčešće frontalna nastava i praktični rad). Postoji statistički značajna razlika između nastavnika s nastavničkim i nenastavničkim studijem ( $M_{\text {nas }}=3,88 ; M_{\text {nenas }}=$ 2,$90 ; t=3,8636 ; p=0,000$ ). Nastavnici s nenastavničkih studija češće su imali organiziranu nastavu u frontalnom obliku rada.

Nastavnici biologije i kemije međusobno se razlikuju u dvije tvrdnje (tablica 5.).

Tablica 5 T-test za nastavnike biologije i kemije

\begin{tabular}{|c|c|c|c|c|c|c|}
\hline & M & SD & M biologija & M kemija & t & p \\
\hline $\begin{array}{c}\text { Tijekom obrazovanja moje znanje predmeta } \\
\text { provjeravano je: }\end{array}$ & 2,55 & 0,845 & 2,69 & 2,18 & 0,3420 & 0,001 \\
\hline \begin{tabular}{c} 
Obrazovanje metodike sam prošao/la uglavnom: \\
\hline
\end{tabular} & 3,60 & 1,737 & 3,90 & 3,05 & 2,879 & 0,005 \\
\hline
\end{tabular}

Nastavnici biologije su nešto češće ispitivani i usmenim isptivanjem i pisanim zadaćama, dok su nastavnici kemije češće pitani samo usmenom provjerom. Nastavnici kemije su u većem broju prošli obrazovanje metodike $u$ frontalnom obliku rada od nastavnika biologije. Ovdje ne treba zaboraviti činjenicu da veći broj nastavnika kemije nije završilo nastavnički studij (62 \%) već je potrebnu kvalifikaciju za rad u školi dobilo kroz dopunsko pedagoško obrazovanje, koje je na različitim Sveučilištima u Hrvatskoj imalo različiti broj sati pojedinog predmeta, različit način izvođenja nastave te provjere znanja (Petričević 1997).

\section{ZAKLUČAK}

Rezultati pokazuju da se nastavnici ne smatraju dobro osposobljenima tijekom studija za praćenje i ocjenjivanje učeničkih postignuća te procjenjuju da ih predmeti potrebni za osposobljavanje nastavnika nisu dobro pripremili za stvarne situacije u nastavničkoj praksi. Slični rezultati dobiveni su i istraživanjem koje su proveli Radeka i Sorić (2005) koje je pokazalo da se nastavnici smatraju dobro osposobljenim za nastavnički posao, ali prema njihovom mišljenju to nije zasluga nastavničkih studija ili dopunskog pedagoškog obrazovanja već njihovog usavršavanja tijekom rada i to u organizaciji strukovnih udruga i spontanom razmjenom iskustva i rukovođeni prvenstveno osobnim motivima (Radeka, Sorić, 2005).

Ispitanici smatraju da tema vrednovanja učeničkih postignuća nije dovoljno dobro zastupljena tijekom obrađivanja sadržaja metodike. Velika većina nastavnika ne primjenjuje kasnije u svom radu 
način praćenja i ocjenjivanja učeničkih postignuća koji su naučili tijekom obrazovanja, što nije čudno obzirom da nisu stekli velika saznanja o vrednovanju tijekom studija.

Tijekom desetljeća nastavnički studiji su se mijenjali po godinama studiranja (od dvije na četiri godine, pa na tri tj. pet), po vrsti predmeta i njihovoj zastupljenosti u nastavnom planu i programu studija (uglavnom se broj predmeta i sati povećavao). Čini se, pak, da su stariji nastavnici zadovoljniji svojim pedagoškim obrazovanjem od mlađih kolega.

Žalosna je činjenica da su jednako nezadovoljni svojim obrazovanjem nastavnici s nastavničkih studija i nastavnici koji su svoje obrazovanje stekli na tečaju koji traje tri do šest mjeseci, ovisno o vremenu polaganja i Sveučilištu na kojem su polagali pedagoško- psihološku grupu predmeta. Istraživanje koje je proveo Petričević (1997) pokazalo je da je za 21,2 \% nastavnika dopunsko pedagoško obrazovanje puno pridonijelo osamostaljivanju nastavnika u obavljanju nastavnih zadaća, za 54,0 \% dosta, malo za 19,7 \% nastavnika, a ništa za 5,1 \%. Dakle 2/3 nastavnika je osamostaljeno dopunskim pedagoškim obrazovanjem. Trebaju li nam nastavnički studiji, ako tečaj od 6 mjeseci može postići istu razinu osposobljenosti i (ne)zadovoljstva stečenim kompetencijama?

Obrazovanje nastavnika u osnovi je kontradiktorno pedagoškom modelu koji se traži od nastavnika u učionici, gdje nastavnik treba provoditi aktivno učenje, poticati kritičko razmišljanje, kreativnost, a to oni sami nisu iskusili u procesu vlastite edukacije i izobrazbe. Nastavnici su obrazovani uglavnom frontalnim oblikom rada kroz predavanja, pasivno, a najčešće su morali memorirati podatke. Jednako tako, iskustvo vrednovanja znanja nastavnika za vrijeme obrazovanja za nastavničke poslove je neusklađeno s novom paradigmom provjeravanja znanja. Da bi nastavnik mogao učinkovito povezivati dijagnostičko i formativno provjeravanje $i$ pri tom obuhvatiti različite situacije treba ovladati tehnikama opažanja, ispitivanja, opisivanja, mora imati razvijene spretnosti planiranja i organiziranja takvih situacija učenja u kojima učenici mogu imati ulogu aktivnih stvaratelja svojeg znanja.

Ako većina prosvjetnih djelatnika nije ocjenjivački pismena na početku svojeg nastavničkog posla možemo zamisliti koliki je to gubitak za učenike kojima takvi nastavnici ne mogu pomoći u razvijanju postignuća; kako onda možemo očekivati usklađenost unutrašnje i vanjske evaluacije; kako očekivati od naše javnosti da razumije pitanja povezana s ocjenjivanjem?

\section{METODIČKI ZNAČAJ}

Rezultati istraživanja ukazuju na važnost promjene u edukaciji nastavnika, prije svega već na nastavničkim studijima, a nakon toga i u sklopu cjeloživotnog obrazovanja nastavnika. Upravo to je jedan od segmenata gdje su nužne velike promjene jer bez promjena u praćenju i vrednovanju učenika nije moguće postići stvarnu promjenu u školskom sustavu. Rad je također ukazao na svijest nastavnika o problemima s kojima se svakodnevno susreću u radu s vrednovanjem učenika.

\section{LITERATURA}

Andrilović V., Čudina-Obradović M. 1996. Psihologija učenja i nastave. Školska knjiga, Zagreb Blažević, I., Jukić, T. 2004. Motivacija učitelja za permanentno usavršavanje i oblici stručnog usavršavanja. Školski vjesnik, 34, 173-184.

Bognar L., Matijević M. 2002. Didaktika. Školska knjiga, Zagreb.

Cindrić, M. 2003. (Re)afirmacija učiteljske obrazovne kompetencije. Odgoj, obrazovanje i pedagogija u razvitku hrvatskog društva: zbornik radova, Sabora pedagoga Hrvatske, ur. H. Vrgoč, HPKZ, Zagreb, 84-92. 
Domović, V. , Matijević, M. 2002. Changes in Education of Teachers in Europe. Metodika (special issue). University of Zagreb, Teacher Education Academy: Zagreb.

Ischinger, B. 2009. Making the teaching profession more attractive: OECD insights, dostupno 01.09.2010. http://www.se2009.eu/polopoly fs/1.16168!menu/standard/file/OECDBarbaralschinger-IMM-Sweden230909Final1.pdf

Jakelić, F. 1996. Racionalno usmjeravanje u učiteljsko zvanje. Pedagogija i hrvatsko školstvo: jučer, danas, sutra, 430-435. ur. H. Vrgoč, Hrvatsko-pedagoško-književni zbor, Zagreb.

Klapan A. 1990. Nastavna praksa studenata na nastavničkim fakultetima. Pedagoški rad, 45,2, 172-177.

Kosinac, Z. 2003. Djelotvornost aktualnoga nastavnog plana i program za izobrazbu učitelja kroz evaluaciju studentica. Život i škola, 9, $50-58$.

Kosinac, Z. 2003a. Analiza gledišta studentica završne godine studija Visoke učiteljske škole u Splitu o zatupljenosti i kakvoći metodika Odgoj, obrazovanje i pedagogija u razvitku hrvatskog društva: zbornik radova, Sabora pedagoga Hrvatske, ur. H. Vrgoč, HPKZ, Zagreb, 613-619.

Kovačević A., Žarnić B. 2003. Model obrazovanja učitelja i odgojitelja u Irskoj, Sloveniji i Hrvatskoj. Školski vjesnik, 1-2, 87102.

Lavrnja, I. 1999. Didaktičko-metodičko osposobljavanje učitelja kao pretpostavka kvalitete rada. Nastavnik-čimbenik kvalitete u odgoju i obrazovanju, zbornik radova, ur. V. Rosić, Rijeka, 30.- 35.

Marinković R., Davidović-Mušica N. 2005. Razvijanje kompetencija kroz hrvatski obrazovni sustav: suprotstavljena gledišta profesionalaca, Napredak, 146,4, 468-476.

Milat, J. 1995. Teze za promjene u sustavu obrazovanja nastavnika. Promjene u sustavu obrazovanja nastavnika: znanstven kolokviju povodu obilježavanja 50. obljetnice djelovanja nastavničkih studija u Splitu, ur. Josip Milat, Fakultet prirodoslovno-matematičkih znanosti i odgojnih područja, Split, 1995.

Mužić V., Vrgoč H. 2005. Vrjednovanje u odgoju i obrazovanju. Hrvatsko-pedagoško-književni zbor, Zagreb.

Nazor, M. 1995. Obrazovanje nastavnika. Promjene u sustavu obrazovanja nastavnika: znanstveni kolokviju povodu obilježavanja 50. obljetnice djelovanja nastavničkih studija u Splitu, ur. Josip Milat, Fakultet prirodoslovnomatematičkih znanosti i odgojnih područja, Split, 1995.

Palekčić M. 2008. Uspješnost i/ili učinkovitost obrazovanja nastavnika. Odgojne znanosti, 10, 2, 403-423.

Pastuović, N.1999. Edukologija. Znamen, Zagreb.

Petričević D. 1997. Dopunsko pedagoško obrazovanje učitelja i nastavnika sa završenim nenastavničkim fakultetima i školama. Napredak, 138, 1, 39-49.

MPS 1995. Pravilnik o načinu praćenja i ocjenjivanja učenika u osnovnoj i srednjoj školi. Narodne novine, 92.

MZOS 2010. Prijedlog izmjena i dopuna pravilnika načinu praćenja i ocjenjivanja učenika u osnovnoj školi, gimnazijama te općeobrazovnih predmeta u strukovnim i umjetničkim školama, Narodne novine, 112/2010, dostupno 28. 08. 2010. nvurh.skole.hr/upload/nvurh/newsattach/56/Pravilnik.pdf.

Radeka I., Sorić I. 2005. Kvaliteta permanentnog usavršavanja nastavnika. Zbornik Učiteljske akademije u Zagrebu, 2, 263277.

Radeka I., Sorić I. 2005a. Model permanentnog usavršavanja nastavnika. Pedagogijska istraživanja, Zagreb, 1, 17-34.

Radeka I., Sorić I. 2006. Zadovoljstvo poslom i profesionalni status nastavnika. Napredak, Zagreb, 2, 161-177.

Razdevšek-Pučko, C. 2002. Nacionalni testovi znanja - izazov, poticaj ili zamka? Zbornik Praćenje i ocjenjivanje školskog uspjeha, str.18-38, ur. H. Vrgoč, Hrvatsko-pedagoško-književni zbor, Zagreb.

Rijavec M., Miljević-Riđički R., Vizek Vidović V. 2006. Professional beliefs and perceived competences of pre-service teachers and beginning teachers. Odgojne znanosti, 8, 1, 159-170.

Rosić, V. 1995. Pedagoško obrazovanje nastavnika. Promjene u sustavu obrazovanja nastavnika: znanstveni kolokviju povodu obilježavanja 50. obljetnice djelovanja nastavničkih studija u Splitu, ur. Josip Milat, Fakultet prirodoslovno-matematičkih znanosti i odgojnih područja, Split.

Vizek Vidović V., Rijavec M., Vlahović-Štetić Vesna i Miljković D. 2003. Psihologija obrazovanja. IEP:VERN, Zagreb.

Vizek Vidović, V., Domović, V. 2008. Researching Teacher Education and Teacher Practice: the Croatian Perspective. In: Hudson, B. \& Zgaga, P. (Eds.) Teacher Education Policy in Europe Network. Umea: Faculty of Teacher Education, University of Umea and Centre for Educational Policy Studies, University of Ljubljana, 303-313.

Vrgoč H. 2002. Zbornik Praćenje i ocjenjivanje školskog uspjeha. ur. H. Vrgoč, Hrvatsko-pedagoško-književni zbor, Zagreb, 18-38.

Vrcelj, S., Mušanović, M. 2003. Reforma školstva - jesu li moguće promjene škole? Odgoj, obrazovanje i pedagogija u razvitku hrvatskog društva: zbornik radova, Sabora pedagoga Hrvatske, ur. H. Vrgoč, HPKZ, Zagreb, 342-348.

Zekanović, N. 1999. Pedagoška izobrazba predmetnih nastavnika u funkciji njihove profesionalizacije. Nastavnik-čimbenik kvalitete u odgoju i obrazovanju, zbornik radova, ur. V. Rosić, Rijeka, 349-357. 